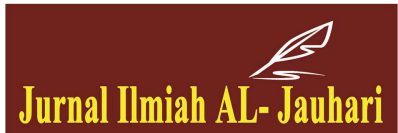

Jurnal Ilmiah AL-Jauhari: Jurnal Studi Islam dan Interdisipliner

Volume 5 No 1, (April 2020): Halaman 23-46

ISSN (Print): 2541-3430, ISSN (Online): 2541-3449

Website: http://journal.iaingorontalo.ac.id/index.php/aj

\title{
Standar Penilaian Kompetensi Pedagogik Guru Pendidikan Agama Islam di SMA Negeri 1 Tapa
}

Sitti Masturiwaty Huntojungo

(Kementerian Agama Kabupaten Bone Bolango)

sitimasturiwaty@yahoo.co.id

\begin{abstract}
Teacher pedagogic competence has an important role in the quality of learning. Every teacher must be able to master the indicators that exist in pedagogical competence, to achieve the quality of learning. The purpose of this study was to analyze the process of implementing teacher pedagogical competency assessment standards and their impact on the performance of Islamic Religious Education teachers at State Senior High School 1 Tapa. The research method uses descriptive qualitative.

Research shows that: 1) the implementation of pedagogical competency assessment standards for Islamic Religious Education teachers has not been carried out by existing indicators. The mismatch was found between the observations of learning and the value of each indicator obtained. Every value from each learning indicator should be an implementation of each learning indicator. 2) there is an overlap in every indicator that exists in other aspects of pedagogical competence, it should be related to each indicator in each aspect. 3) every indicator of pedagogical competence has not been maximally implemented. 4) the impact of the implementation of pedagogical competency assessment standards on the performance of Islamic Religious Education teachers has positive and negative effects both for teachers, students, and schools.
\end{abstract}




\begin{abstract}
Abstrak
Kompetensi pedagogik guru mempunyai peranan penting dalam kualitas pembelajaran. Setiap guru harus mampu menguasai indikator-indikator yang ada dalam kompetensi pedagogik, demi tercapai kualitas pembelajaran. Tujuan penelitian ini adalah untuk menganalisis proses pelaksanaan standar penilaian kompetensi pedagogik guru dan dampaknya terhadap kinerja guru Pendidikan Agama Islam di SMA Negeri 1 Tapa. Metode Penelitian menggunakan deskriptif kualitatif.

Penelitian menunjukkan bahwa: 1) pelaksanaan standar penilaian kompetensi pedagogik untuk guru Pendidikan Agama Islam belum dijalankan sesuai dengan indikator yang ada. Ditemukan ketidaksesuaian antara hasil pengamatan belajar dan nilai pada setiap indikator yang diperoleh. Seharusnya setiap nilai dari setiap indikator pembelajaran merupakan implementasi dari setiap indikator pembelajaran. 2) terjadi tumpang tindih pada setiap indikator yang ada pada aspek kompetensi pedagogik yang lain, seharunya antar indikator pada setiap setiap aspek memiliki keterkaitan. 3) setiap indikator pada kompetensi pedagogik belum terlaksana secara maksimal. 4) dampak dari pelaksanaan standar penilaian kompetensi pedagogik terhadap kinerja guru Pendidikan Agama Islam menimbulkan pengaruh positif dan negatif baik bagi guru, peserta didik dan sekolah.
\end{abstract}

Kata Kunci : Standar Penilaian, Kompetensi, Pedagogik

\title{
Pendahuluan
}

Guru merupakan salah satu faktor penentu keberhasilan sebuah proses pendidikan. Kedudukan guru tidak dapat digantikan oleh media lain, meskipun saat ini teknologi komputer berkembang dengan pesat menggantikan sebagian besar pekerjaan manusia. Berkaitan dengan itu, maka guru akan menjadi bahan pembicaraan banyak orang. Berhasil tidaknya pendidikan selalu dihubungkan dengan kinerja para guru. Oleh karena itu, usaha-usaha untuk meningkatkan mutu pendidikan selalu dimulai dari usaha peningkatan kualitas kinerja dari guru. Guru harus lebih dinamis dan kreatif dalam mengembangkan proses pembelajaran peserta didik.

Proses belajar mengajar merupakan inti dari proses pendidikan secara keseluruhan dengan guru sebagai pemegang peranan utama. Proses belajar mengajar secara sederhana dapat diartikan sebagai kegiatan interaksi dan saling mempengaruhi antara guru dan peserta didik, dengan fungsi utama guru memberikan materi pelajaran atau 
sesuatu yang mempengaruhi peserta didik, sedangkan peserta didik menerima pelajaran, pengaruh atau sesuatu yang diberikan oleh guru. ${ }^{1}$

Peran guru dalam penyelenggaraan pendidikan sangat dominan terhadap pencapaian kualitas pendidikan. Oleh karenanya upaya mempersiapkan sumber daya manusia, dalam hal ini seorang guru yang profesional perlu penegasan konkret seperti yang dijelaskan dalam Undang-undang Republik Indonesia Nomor 14 Tahun 2005 tentang Guru dan Dosen, Pasal 1 Ayat 2 menyatakan bahwa guru adalah pendidik profesional dengan tugas utama mendidik, mengajar, membimbing, mengarahkan, melatih, menilai dan mengevaluasi peserta didik pada pendidikan anak usia dini jalur pendidikan formal, pendidikan dasar, dan pendidikan menengah.

Sebagai pendidik profesional, guru tentu wajib memiliki kompetensi yakni, seperangkat pengetahuan, keterampilan dan perilaku yang harus dimiliki, dihayati dan dikuasai oleh guru dalam melaksanakan tugas keprofesionalannya. Hal ini menunjukkan bahwa kompetensi yang harus dimiliki guru dalam melaksanakan tugas keprofesionalannya adalah kompetensi yang utuh dan integratif. Kompetensi yang dimiliki oleh guru bukan sebatas pengetahuan tentang tugas-tugas profesionalnya saja, seperti tentang cara mendidik, mengajar, membimbing, mengarahkan, melatih, menilai dan mengevaluasi peserta didik. Tetapi pengetahuan itu tidak dijiwai dan tidak diterapkan oleh guru secara konsekuen, konsisten dan terampil. Hal ini tentu percuma saja seorang guru memiliki pengetahuan, jika pengetahuan tersebut tidak terwujud dalam tindakan, sehingga tidak memberikan makna dan manfaat bagi pelaksanaan pendidikan secara nyata.

Secara konstitusional berdasarkan Undang-undang RI No. 14 Tahun 2005 tentang Guru dan Dosen, Pasal 10, Ayat (1) bahwa kompetensi yang wajib dikuasai oleh guru meliputi: 1) Kompetensi pedagogik adalah kemampuan mengelola pembelajaran peserta didik; 2) Kompetensi kepribadian adalah kemampuan kepribadian yang mantap, berakhlak mulia, arif dan berwibawa serta menjadi teladan peserta didik; 3) Kompetensi profesional adalah kemampuan penguasaan materi pelajaran secara luas dan mendalam; 4) Kompetensi sosial adalah kemampuan guru untuk berkomunikasi dan berinteraksi secara efektif dan efisien dengan peserta didik, sesama guru, orang tua/wali peserta didik dan masyarakat sekitar. ${ }^{2}$

\footnotetext{
${ }^{1}$ Abuddin Nata, Ilmu Pendidikan Islam, (Jakarta: Kencana Prenada Media Group, 2010), h. 139.

${ }^{2}$ Undang-Undang RI No. 14 Th 2005, Tentang Guru dan Dosen, (Jakarta: Asa Mandiri, 2007), h. 10
} 
Keempat kompetensi tersebut di atas bukan hanya wajib dimiliki, dihayati, dan dikuasai oleh guru, tetapi juga wajib ditingkatkan dan dikembangkan oleh guru secara utuh dan terus menerus dan dinamis. Hal ini sebagaimana diamanatkan dalam Undang-undang RI No. 14 Tahun 2005 tetang Guru dan Dosen, Pasal 20, huruf (b) bahwa dalam melaksanakan tugas dan keprofesionalan, guru wajib meningkatkan dan mengembangkan kualifikasi akademik dan kompetensi secara berkelanjutan sejalan dengan perkembangan ilmu pengetahuan, teknologi dan seni.

Fenomena yang sering terjadi adalah para guru yang belum memenuhi kualifikasi sebagai guru yang berkompeten, khususnya kompetensi pedagogik yang berkaitan dengan pengelolaan pembelajaran. Guru tidak lagi bertindak sebagai penyaji informasi tetapi juga harus mampu bertindak sebagai fasilitator, motivator, maupun pembimbing yang senantiasa berupaya memaksimalkan perkembangan potensi yang dimiliki peserta didik. Perluasan tugas dan tanggung jawab guru tersebut membawa konsekuensi timbulnya fungsi-fungsi khusus yang menjadi bagian integral dalam kompetensi pedagogik yang disandang oleh guru. Menurut Gagne, setiap guru berfungsi sebagai designer of instruction (perancang pengajaran), manager of instruction (pengelola pengajaran) dan evaluator of student learning (penilai prestasi belajar siswa). ${ }^{3}$

Masih rendahnya kompetensi pedagogik dapat dilihat dari banyaknya guru yang belum memahami karakteristik, kebutuhan dan perkembangan peserta didik. Guru belum menguasai konsep, prinsip dan prosedur pengembangan kurikulum. Guru belum dapat menciptakan situasi pembelajaran yang interaktif, inspiratif, menyenangkan, menantang, memotivasi peserta didik untuk berpartisipasi aktif, serta memberi ruang yang cukup bagi prakarsa, kreatifitas dan kemandirian.

Kinerja guru merupakan prestasi yang diperlihatkan dalam bentuk perilaku. Kinerja adalah hasil kerja secara kualitas dan kuantitas yang dicapai seseorang dalam melaksanakan tugasnya sesuai dengan tanggung jawab yang diberikan kepadanya. ${ }^{4}$ Kinerja guru merupakan prestasi guru sebagai hasil dorongan yang diperlihatkan dalam bentuk perilaku. Selain itu kinerja juga dapat diartikan sebagai suatu hasil usaha seseorang yang dicapai dengan adanya kemampuan dan perbuatan dalam situasi tertentu.

\footnotetext{
${ }^{3}$ Muhibbin Syah, Psikologi Pendidikan dengan Pendekatan Baru, (Bandung: PT. Remaja Rosdakarya, 1997), h. 255.

${ }^{4}$ Imam Wahyudi, Pengembangan Pendidikan Strategi Inovatif \& Kreatif dalam Mengelola Pendidikan Secara Komprehensif, (Jakarta: PT. Prestasi Pustakaraya, 2012), h. 128
} 
Namun dalam implementasi di lapangan motivasi kerja dan kinerja guru sangatlah kompleks yang melatar belakanginya. Belum adanya kesamaan semangat antara guru satu dengan yang lainnya sehingga terdapat kesenjangan dalam mengimplementasikan peraturan dan visi sekolah yang diharapkan. Guru dianggap masih kurang memiliki inisiatif dalam mengambil langkah untuk kemajuan sekolah. Dalam konteks pekerjaan, motivasi merupakan salah satu faktor penting dalam mendorong seorang karyawan untuk bekerja. Karena pada dasarnya motivasi dapat bersumber pada diri seseorang yang dikenal dengan motivasi instrinsik dan dapat juga berasal dari luar diri seseorang (motivasi instrinsik).

Dari berbagai uraian tersebut di atas, maka rendahnya motivasi kerja guru dan masih rendahnya kinerja guru memberikan dampak yang serius bagi peningkatan kompetensi pedagogik seorang guru dalam menjalankan tugasnya.

Di SMA Negeri Tapa, implementasi kompetensi pedagogik guru dalam upaya peningkatan kinerja guru telah terlaksana sebagaimana mestinya, termasuk di dalamnya penilaian pada guru mata pelajaran Pendidikan Agama Islam. Walaupan dalam pencapaiannya, nilai kompetensi pedagogik guru belum terpenuhi secara masksimal. Namun upaya untuk peningkatan kompetensi pedagogik guru Pendidikan Agama Islam terus dilakukan.

Pengamatan awal yang peneliti peroleh bahwa terdapat ketidak sesuaian antara hasil pengamatan pembelajaran dan skor dari setiap indikator yang diperoleh oleh guru tersebut. Di sisi lain masih kurangnya pemahaman guru Pendidikan Agama Islam dalam memahami setiap indikator pembelajaran serta bagaimana mengimplementasikannya pada proses pembelajaran. Dengan demikian guru sulit untuk mencapai skor maksimal sesuai dengan ketentuan penilaian.

Kenyataan tersebut tentunya memberikan dampak bagi pelaksanaan pembelajaran maupun dampak bagi guru Pendidikan Agama Islam dalam proses penilaian kinerja guru dan upaya peningkatan karirnya. Hal ini tentunya perlu mendapat tindak lanjut agar pelaksanaan proses pembelajaran dapat berjalan efektif.

\section{Standar Penilaian Kompetensi Pedagogik Guru Pendidikan Agama Islam}

Menurut Peraturan Menteri Negara Pendayagunaan Aparatur Negara dan Reformasi Birokrasi Nomor 16 Tahun 2009, penilaian kinerja guru adalah penilaian yang dilakukan terhadap setiap butir kegiatan tugas utama guru dalam rangka pembinaan karir, kepangkatan, dan jabatannya. Guru sebagai 
pendidik profesional mempunyai tugas utama yaitu mendidik, mengajar, membimbing, mengarahkan, melatih, menilai dan mengevaluasi peserta didik pada pendidikan anak usia dini jalur pendidikan formal, pendidikan dasar, dan pendidikan menengah. ${ }^{5}$

Penilaian kinerja adalah proses menilai hasil karya personel dalam suatu organisasi melalui instrument penilaian kerja. Pada hakikatnya, penilaian kinerja merupakan suatu evaluasi terhadap penampilan kerja personel dengan membandingkannya dengan standar buku penampilan. Kegiatan penilaian kinerja ini membantu pengambilan keputusan bagian personalia dan memberikan umpan balik kepada para personel tentang pelaksanaan kerja mereka. ${ }^{6}$

Pelaksanaan tugas utama guru tidak dapat dipisahkan dari kemampuan seorang guru dalam penguasaan dan penerapan kompetensinya, seperti yang diamanatkan dalam Peraturan Menteri Pendidikan Nasional Nomor 16 Tahun 2007 tentang Standar Kualifikasi Akademik dan Kompetensi Guru, khususnya pada penguasaan kompetensi pedagogik dan kompetensi profesional. Penguasaan dan penerapan kompetensi tersebut sangat menentukan tercapainya kualitas proses pembelajaran, pembimbingan peserta didik, dan pelaksanaan tugas tambahan yang relevan yang sesuai dengan fungsi sekolah/madrasah. Untuk memastikan apakah guru melaksanakan tugasnya secara profesional maka perlu dikembangkan sistem penilaian kinerja guru.

Sistem penilaian kinerja guru adalah sebuah sistem penilaian kinerja berbasis bukti (evidence-based appraisal) yang didesain untuk mengevaluasi tingkatan kinerja guru secara individu dalam melaksanakan tugas utamanya sebagai guru profesional. Penilaian kinerja guru diharapkan berimplikasi positif terhadap perbaikan dan peningkatan profesionalisme guru, juga harus berdampak pada peningkatan prestasi peserta didik. Sistem ini merupakan bentuk penilaian yang sangat penting untuk mengukur kinerja guru dalam melaksanakan pekerjaannya sebagai bentuk akuntabilitas sekolah. Pada dasarnya syarat sistem penilaian kinerja guru adalah :

1. Valid; sistem penilaian kinerja guru dikatakan valid bila aspek yang dinilai benar-benar mengukur komponenkomponen tugas guru dalam melaksanakan pembelajaran,

\footnotetext{
${ }^{5}$ Jaringan Dokumentasi dan Informasi Hukum, Permenpan 2009 No. 16, http://www.menpan.go.id/jdih/permen-kepmen/permenpan-rb/file/277-permenpan2009-no-016?start=140, diakses tanggal 06 Maret 2017.

${ }^{6}$ Yaslis Ilyas, Kinerja: Teori, Penilaian, dan Penelitian. Depok: FKMUI, 2002., h. 87
} 
pembimbingan, dan/atau tugas lain yang relevan dengan fungsi sekolah/madrasah.

2. Reliabel; sistem penilaian kinerja guru dikatakan reliabel atau mempunyai tingkat kepercayaan tinggi jika proses yang dilakukan memberikan hasil yang sama untuk seorang guru yang dinilai kinerjanya oleh siapapun dan kapanpun

3. Praktis; sistem penilaian kinerja guru dikatakan praktis bila dapat dilakukan oleh siapapun dengan mudah, dengan tingkat validitas dan reliabilitas yang sama dalam semua kondisi tanpa memerlukan persyaratan tambahan. ${ }^{7}$

Dalam konteks Peraturan Menteri Negara Pendayagunaan Aparatur Negara dan Reformasi Birokrasi Nomor 16 Tahun 2009 tentang Petunjuk Teknis Jabatan Fungsional Guru dan Angka Kreditnya, penilaian kinerja guru memiliki dua fungsi utama, yaitu untuk:

1. Menilai unjuk kerja (kinerja) guru dalam menerapkan semua kompetensi yang diwujudkan dalam pelaksanaan tugas utamanya pada proses pembelajaran, pembimbingan atau pelaksanaan tugas tambahan yang relevan dengan fungsi sekolah/madrasah. Dengan demikian, hasil penilaian kinerja menjadi profil kinerja guru yang dapat memberikan gambaran kekuatan dan kelemahan guru. Profil kinerja guru juga dapat dimaknai sebagai suatu analisis kebutuhan atau audit keterampilan untuk setiap guru yang dapat dipergunakan sebagai dasar untuk merencanakan pengembangan keprofesian berkelanjutan bagi guru.

2. Menghitung angka kredit yang diperoleh guru atas kinerja pembelajaran, pembimbingan atau pelaksanaan tugas tambahan yang relevan dengan fungsi sekolah/madrasah pada tahun penilaian kinerja guru dilaksanakan. Kegiatan penilaian kinerja dilakukan setiap tahun sebagai bagian dari proses pengembangan karir dan promosi guru untuk kenaikan pangkat dan jabatan fungsionalnya. ${ }^{8}$

Kompetensi pedagogik merupakan kompetensi instruksional edukatif (mengajar dan mendidik) yang esensial dan fundamental bagi guru dalam pelaksanaan tugas keprofesionalannya, terutama tugas mendidik, mengajar, membimbing, mengarahkan, melatih, menilai dan mengevaluasi peserta didik. Dalam Peraturan Pemerintah

\footnotetext{
${ }^{7}$ Direktorat Jenderal Peningkatan Mutu Pendidik dan Tenaga Kependidikan, Pedoman Pelaksanaan Penilaian Kinerja Guru (PK Guru). Kementerian Pendidikan Nasional., 2010, h. 4

${ }^{8}$ Ibid., h. 3
} 
RI Nomor 19 Tahun 2005 tentang Standar Nasional Pendidikan, penjelasan Pasal 28 ayat (3) butir (a) dikemukakan bahwa:

"Kompetensi pedagogik adalah kemampuan mengelola pembelajaran peserta didik yang meliputi pemahaman terhadap peserta didik, perancangan, pelaksanaan pembelajaran, evaluasi hasil belajar dan pengembangan peserta didik untuk mengaktualisasikan beragai potensi yang dimilikinya." 9

Kompetensi pedagogik adalah kemampuan guru berkenaan dengan penguasaan teoritis dan proses aplikasinya dalam pembelajaran. Berdasarkan Peraturan Menteri Pendidikan Nasional Nomor 35 Tahun 2010 tentang Petunjuk Teknis Pelaksanaan Jabatan Fungsional Guru dan Angka Kredit terdapat tujuh kompetensi pedagogik. ${ }^{10}$

Kinerja Guru pada hakikatnya merupakan suatu kegiatan untuk membina dan mengembangkan guru profesional yang dilakukan dari guru, oleh guru dan untuk guru. Selain itu pula kinerja guru diperlukan untuk mendeskripsikan dan memetakan kinerja guru sesuai dengan tugas dan fungsinya yang sesuai dengan prinsip mendasar bahwa guru harus menjadi pembelajar sepanjang hayat yang senantiasa belajar. Guru juga berkewajiban untuk senantiasa meningkatkan kompetensi dan mempertahankan profesionalitasnya karena guru profesional memiliki tugas dan fungsi serta kedudukan yang sangat strategis dalam mempersiapkan generasi bangsa yang cerdas, mandiri dan produktif.

Penilaian kinerja guru tidak terbatas pada aspek-aspek formal secara langsung berkaitan dengan tugas dan fungsinya, tetapi juga mencakup berbagai aspek terutama yang berkaitan dengan kompetensinya. Terdapat tiga aspek dalam kinerja guru yang meliputi:

1. Kinerja yang terkait dengan pelaksanaan proses pembelajaran bagi guru mata pelajaran atau guru kelas, meliputi kegiatan merencanakan dan melaksanakan pembelajaran, menilai, menganalisis, hasil penilaian dan melaksanakan tindak lanjut hasil penilaian.

\footnotetext{
${ }^{9}$ Permendiknas RI No. 19 Tahun 2005 Tentang Standar Nasional Pendidikan, dalam http://kitaabati.blogspot.com/2012/12/permendiknas-ri-no-19tahun-2005.html, diakses tanggal 03 Maret 2017.

${ }^{10}$ Adapun Potensi pedagogic guru: 1) Menguasai karakter peserta didik; 2) Menguasai teori belajar dan prinsip-prinsip pembelajaran yang mendidik; 3) Pengembangan kurikulum; 4) Kegiatan pembelajaran yang mendidik; 5) Pengembangan potensi peserta didik; 6) Komunikasi dengan peserta didik; 7) Penilaian dan evaluasi. Lihat Nur Irwanto dan Yusuf Suryana, Kompetensi Pedagogik; Untuk Peningkatan dan Penilaian Kinerja Guru dalam Rangka Implementasi Kurikulum Nasional, (Surabaya: Genta Group Production, 2016), h. 3.
} 
2. Kinerja dalam melaksanakan proses pembimbingan bagi guru Bimbingan Konseling (BK)/Konselor yang meliputi kegiatan merencanakan dan melaksanakan pembimbingan, mengevaluasi dan menilai hasil bimbingan, menganalisis hasil evaluasi pembimbingan, memanfaatkan hasil evaluasi dan melaksanakan tindak lanjut hasil pembimbingan.

3. Kinerja yang terkait dengan pelaksanaan tugas tambahan yang relevan dengan fungsi sekolah. Pelaksanaan tugas tambahan ini dikelompokkan menjadi dua, yaitu tugas tambahan yang mengurangi jam mengajar tatap muka dan yang tidak mengurangi jam mengajar tatap muka. ${ }^{11}$

\section{Standar Penilaian Kompetensi Pedagogik Guru}

1. Menguasai Karakter Peserta Didik

Menguasai karekteristik peserta didik berhubungan dengan kemampuan guru dalam memahami kondisi peserta didik. Anak memiliki karakteristik tersendiri yang berbeda satu dengan yang lainnya baik dari segi minat, bakat, motivasi, daya serap mengikuti pelajaran, tingkat perkembangan, tingkat inteligensi, dan memiliki perkembangan sosial tersendiri. Berbagai perbedaan tersebut merupakan faktor yang ikut mempengaruhi prestasi belajar anak. Untuk itu anak diberikan kesempatan mendapatkan apa yang diinginkan sehingga anak dapat berkembang seoptimal mungkin sesuai dengan kemampuan, bakat dan minatnya masing-masing.

Dari standar penilaian kinerja guru Pendidikan Agama Islam pada tahun 2016, nilai untuk kompetensi aspek 1 adalah 4 (kinerja yang sangat baik). Sebagian besar indikator telah terpenuhi dengan skor 2 pada masing-masing indikator. Tetapi pada indikator ke 5 yakni guru membantu mengembangkan potensi dan mengatasi kekurangan peserta didik belum terpenuhi sebagian. Hal ini mengindikasikan bahwa masih perlunya peran guru dalam proses pembelajaran yakni guru lebih aktif dalam berinteraksi dengan setiap peserta didik.

\section{Menguasai Teori Belajar dan Prinsip-prinsip Pembelajaran yang Mendidik}

Penguasaan teori belajar dan prinsip-prinsip pembelajaran yang mendidik sangatlah penting bagi guru dalam upaya mewujudkan pembelajaran yang efektif, efisien dan optimal. ${ }^{12}$

11 Direktorat Jenderal Peningkatan Mutu Pendidik dan Tenaga Kependidikan, Pedoman Pelaksanaan Penilaian Kinerja Guru (PK Guru). Kementerian Pendidikan Nasional., 2010, h. 5

${ }^{12}$ Adapun indikator atau kinerja penguasaan teori belajar dan prinsip-prinsip pembelajaran yang mendidik adalah sebagai berikut : a. Guru memberi kesempatan 
Dari standar penilaian kinerja guru Pendidikan Agama Islam tersebut, terdapat 3 indikator telah terpenuhi dengan skor 2 (terpenuhi seluruhnya) pada masing-masing indikator dan 2 indikator lainnya belum terpenuhi sebagian. Indikator yang dimaksud adalah indikator 3 dan indikator 5. Pada indikator ke 3 guru dianggap belum mampu menjelaskan alasan pelaksanaan kegiatan pembelajaran baik yang sesuai maupun yang berbeda dengan rencana pembelajaran. Dalam hal ini guru belum mampu menjelaskan rencana materi pembelajaran sesuai dengan RPP kepada peserta didik.

Pada indikator ke 5, guru Pendidikan Agama Islam belum mampu memenuhi indikator tersebut secara keseluruhan. Guru dianggap belum mampu merencanakan kegiatan pembelajaran yang saling terkait. Dalam memberikan pembelajaran guru masih berpedoman pada materi yang ada. Di sisi lain guru dituntut untuk kreatif dalam mengelola materi pembelajaran yang saling terkait.

Dengan demikian terjadi korelasi antara indikator ke 3 dan ke 5. Karena guru dianggap tidak kreatif dalam melaksanakan meteri pembelajaran kepada peserta didik. Guru hanya melaksanakan pembelajaran seperti yang telah ditetapkan pada RPP.

Pada pengamatan proses pembelajaran, ketika peserta didik tidak menanggapi pertanyaan dari guru, sang guru tidak berusaha mencari tahu apakah penyebabnya sehingga peserta didik tidak merespon pertanyaan dari guru. Sedangkan pada penilaian kompetensi 2 indikator 4 menyebutkan bahwa guru menggunakan berbagai teknik untuk memotivasi kemauan belajar peserta didik, guru Pendidikan Agama Islam memperoleh skor 2 atau seluruhnya terpenuhi. Dari kedua pernyataan tersebut ditemukan fakta bahwa terjadi tumpang tindih antara hasil pengamatan dan hasil penilaian pada kompetensi 2, sehingga diperlukan penelitian mendalam apa saja yang menjadi kendala tersebut.

kepada peserta didik untuk menguasai materi pembelajaran sesuai usia dan kemampuan belajarnya melalui pengaturan proses pembelajaran dan aktivitas yang bervariasi; $b$. Guru selalu memastikan tingkat pemahaman peserta didik terhadap materi pembelajaran tertentu dan menyesuaikan aktivitas pembelajaran berikutnya berdasarkan tingkat pemahaman; c. Guru menjelaskan alasan pelaksanaan kegiatan yang dilakukannya, baik yang sesuai maupun yang berbeda dengan rencana, terkait keberhasilan pembelajaran; d. Guru menggunakan teknik untuk memotivasi kemauan belajar peserta didik; e. Guru merencanakan kegiatan pembelajaran yang saling terkait satu sama lain, dengan memperhatikan tujuan pembelajaran maupun proses belajar peserta didik; f. Guru memperhatikan respon peserta didik yang belum/kurang memahami materi pembelajaran yang diajarkan dan menggunakannya untuk memperbaiki rancangan pembelajaran berikutnya. 
Secara keseluruan, hasil penilaian tersebut menunjukkan bahwa kompetensi pedagogik guru Pendidikan Agama Islam di SMA Negeri 1 Tapa pada aspek menguasai teori belajar dan prinsip-prinsip pembelajaran yang mendidik sudah menunjukkan kinerja yang baik. Walaupun masih ada beberapa indikator yang terpenuhi sebagian.

\section{Pengembangan Kurikulum}

Kurikulum merupakan salah satu komponen yang memiliki peranan penting dalam sistem pendidikan nasional karena dalam kurikulum bukan arah pendidikan, akan tetapi juga memberikan pemahaman tentang pengalaman belajar yang harus dimiliki setiap peserta didik. Oleh karena itu, begitu pentingnya fungsi dan peran kurikulum, maka setiap pengembangan kurikulum pada jenjang manapun harus didasarkan pada asas-asas tertentu.

Menurut Nana S. Sukmadinata (1988: 4) mengemukakan bahwa kurikulum mempunyai kedudukan yang sentral dalam keseluruhan proses pendidikan. ${ }^{13}$ Adapun fungsi kurikulum adalah kurikulum sebagai rencana, kurikulum sebagai pengaturan, kurikulum sebagai cara dan kurikulum sebagai pedoman. Untuk menempatkan kurikulum pada kedudukan sentral dalam keseluruhan proses pendidikan, institusi pendidikan dan pengajar harus mampu menerjemahkan fungsi tersebut sebagai dinamisator pembelajaran. Tanpa dinamisasi pembelajaran, keberadaan kurikulum akan terabaikan atau hanya sebagai dokumen resmi yang akan ditunjukkan kepada para assesor pada saat akreditasi.

Berdasarkan format penilaian kinerja guru yang berlaku efektif 1 Januari 2013, indikator kompetensi pengembangan kurikulum yang wajib dan dilaksanakan guru adalah:

a. Menyusun silabus yang sesuai dengan kurikulum

b. Merancang rencana pembelajaran yang sesuai dengan silabus untuk membahas materi ajar tertentu agar peserta didik dapat mencapai kompetensi dasar yang ditetapkan

c. Mengikuti urutan materi pembelajaran dengan memperhatikan tujuan pembelajaran

d. Memilih materi pembelajaran yang sesuai.

Dari hasil standar penilaian kompetensi ke 3 tersebut bahwa dari 4 indikator yang dinilai, indikator ke 1, 2, dan 3 memperoleh skor 2 (terpenuhi seluruhnya) dan indikator ke 4 memperoleh skor 1 (terpenuhi sebagian). Jadi total skor untuk kompetensi 3 adalah 7, skor maksimum untuk kompetensi 3 adalah 8. Sehingga nilai persentase

${ }^{13}$ Tedjo Narsoyo Reksoatmodjo, Pengembangan Kurikulum Pendidikan Teknologi dan Kejuruan, (Bandung; PT. Refika Aditama, 2010), h. 4. 
yang diperoleh adalah 87,5 \%. Dengan demikian nilai untuk kompetensi 3 adalah 4 dengan hasil kinerja yang baik.

Dalam pengamatan kegiatan belajar mengajar diperoleh gambaran bahwa guru dapat menjelaskan materi dengan lancar dan jelas sesuai dengan silabus. Selain itu guru dapat melaksanakan langkah-langkah kegiatan pembelajaran. Sehingga pada indikator 1, 2 dan 3 dapat terpenuhi selurunya. Pada indikator ke 4 diperoleh skor 1, adapun kendala yang dihadapi guru adalah guru belum mampu menyesuaikan usia dan tingkat kemampuan belajar setiap peserta didik. Pernyataan tersebut didukung dengan data pada kompetensi mengenal karakteristik peserta didik pada indikator ke 5 (guru belum mampu mengembangkan potensi dan kekurangan peserta didik). Selain itu pula, guru Pendidikan Agama Islam belum mampu menyampaikan materi yang sesuai dengan konteks kehidupan seharihari peserta didik disertai dengan contoh-contoh yang kongkrit.

Penilaian terhadap indikator yang masih terpenuhi sebagian mempunyai dampak yang sangat berpengaruh terhadap peserta didik dan guru Pendidikan Agama Islam. Adapun dampaknya terhadap peserta didik adalah peserta didik tidak dapat menerima materi dengan efektif. Ada peserta didik yang mudah memahami setiap materi yang diajarkan, adapula peserta didik yang sulit dalam memahami materi pelajaran. Hal ini disebabkan karena guru tidak mampu memilih materi yang sesuai dengan tingkat kemampuan setiap peserta didik. Dampak bagi guru Pendidikan Agama Islam adalah guru dianggap tidak mampu mengembangkan kreativitas dirinya dalam mengelola materi pelajaran. Sehingga hal tersebut berpengaruh terhadap penilaian kinerja guru pada aspek pengembangan kurikulum belum terpenuhi seluruhnya.

\section{Kegiatan Pembelajaran yang Mendidik}

Dalam kompetensi ini guru dituntut mampu menyusun dan melaksanakan rancangan pembelajaran yang mendidik secara lengkap, melaksanakan pembelajaran yang sesuai dengan kebutuhan peserta didik, menyusun dan menggunakan berbagai materi pembelajaran dan sumber belajar sesuai dengan karakterisitik peserta didik serta memanfaatkan teknologi informasi komunikasi untuk kepentingan pembelajaran. Adapun indikator kompetensi atau kinerja pada kegiatan pembelajaran yang mendidik adalah sebagai berikut:

a. Guru melaksanakan aktifitas pembelajaran sesuai dengan rancangan yang telah disusun secara lengkap

b. Guru melaksanakan aktivitas pembelajaran yang membantu proses belajar peserta didik 
c. Guru mengkomunikasikan informasi baru sesuai dengan usia dan tingkat kemampuan belajar peserta didik

d. Guru menyikapi kesalahan yang dilakukan peserta didik sebagai tahapan proses pembelajaran, bukan semata-mata kesalahan yang harus dikoreksi

e. Guru melaksanakan kegiatan pembelajaran sesuai isi kurikulum dan mengaitkannya dengan konteks kehidupan sehari-hari.

f. Guru melakukan aktivitas pembelajaran secara bervariasi dengan waktu yang cukup untuk kegiatan pembelajaran yang sesuai dengan usia dan tingkat kemampuan belajar dan mempertahankan perhatian peserta didik

g. Guru mengelola kelas dengan efektif tanpa mendominasi atau sibuk dengan kegiatannya sendiri agar semua waktu peserta dapat dimanfaatkan secara produktif

h. Guru mampu menyesuaikan aktivitas pembelajaran yang dirancang dengan kondisi kelas

i. Guru memberikan kesempatan kepada peserta didik untuk bertanya dan berinteraksi dengan peserta didik lain

j. Guru mengatur pelaksanaan aktivitas pembelajaran secara sistematis untuk membantu proses belajar peserta didik.

k. Guru menggunakan alat bantu mengajar dan atau audio visual untuk meningkatkan motivasi belajar peserta didik dalam mencapai tujuan pembelajaran

Pada standar penilaian kompetensi 4 tersebut guru Pendidikan Agama Islam memperoleh nilai 4, walaupun pada indikator ke 3, 4, 6, 7 dan 11 memperoleh skor 1 dari 11 indikator yang dinilai. Pada proses pengamatan pembelajaran, guru masih memberikan materi dengan menggunakan media papan tulis, sehingga indikator ke 11 yakni penggunaan alat bantu mengajar dan atau audio visual untuk peningkatan motivasi belajar peserta didik belum terpenuhi seluruhnya. Hal ini disebabkan karena guru Pendidikan Agama Islam lebih memilih penyampaian informasi hanya melalui bahasa verbal dan media papan tulis.

Selain itu pada indikator 3 (mengkomunikasikan informasi baru) dan indikator 6 (pelaksanaan kegiatan pembelajaran secara bervariasi dengan waktu yang cukup), guru Pendidikan Agama Islam memperoleh skor 1. Hal tersebut disebabkan karena guru kurang kreatif dalam menciptakan suasana pembelajaran yang efektif. Guru hanya melaksanakan langkah-langkah pembelajaran yang sesuai dengan RPP tanpa ada pengembangan lebih lanjut selama proses pembelajaran.

Pada indikator ke 7 (mengelola kelas dengan efektif tanpa sibuk dengan kegiatan sendiri), guru tersebut memperoleh skor 1 
dengan indikasi bahwa indikator ke 7 belum terpenuhi keseluruhan. Kendala yang dihadapi adalah masih terbaginya waktu guru antara pemenuhan kebutuhan pribadi dan kegiatan belajar mengajar pada jam sekolah.

Adapun hasil analisis yang penulis peroleh berdasarkan observasi dan hasil penilaian kompetensi kegiatan pembelajaran yang mendidik adalah bahwasanya guru masih lebih sering menggunakan media papan tulis walaupun fasilitas pembelajaran untuk media audio visual telah tersedia. Hal ini berpengaruh pada penilaian indikator yang ke 11, yaitu penggunaan alat bantu ajar hanya memperoleh skor 1 (terpenuhi sebagian). Guru belum mampu beradaptasi dengan perkembangan teknologi informasi pada perangkat media pembelajaran saat ini. Hal ini tentu akan berdampak bagi tingkat pemahaman materi peserta didik yang berbeda-beda. Selain itu kendala yang dihadapi oleh guru Pendidikan Agama Islam adalah jam pelajaran untuk mata pelajaran PAI masih sering terganggu dengan urusan pribadi. Peserta didik akan merasakan langsung dampaknya, karena guru dianggap tidak bisa memberikan waktu belajar secara penuh bagi peserta didik. Sehingga bisa berdampak bagi pemenuhan jam mata pelajaran guru Pendidikan Agama Islam.

Guru Pendidikan Agama Islam belum mampu memberikan informasi-informasi terbaru ataupun materi tambahan yang berhubungan dengan materi pembelajaran. Dari berbagai kendala yang dihadapi guru Pendidikan Agama Islam tersebut tentunya memberikan pengaruh terhadap proses pembelajaran dan hasil yang dicapai oleh setiap peserta didik. Pada indikator ke 4 guru memperoleh skor 1 . Guru dianggap belum mampu menyikapi kesalahan yang dilakukan peserta didik sebagai suatu proses, bukan sebagai suatu kesalahan. Karena pada prinsipnya bahwa pembelajaran yang mendidik hendaknya berlangsung sebagai suatu proses pembelajaran yang diselenggarakan secara interaktif, inspiratif dan memotivasi peserta didik untuk berpartisipasi aktif. Pada pembelajaran, guru Pendidikan Agama Islam masih sering menyikapi kesalahan sebagai suatu hukuman ataupun punishment, bukan sebagai motivasi bagi peserta didik dalam pembelajaran. Dampak yang langsung dirasakan oleh peserta didik adalah akan muncul perasaan takut sehingga akan menghambat proses belajar dan perkembangan psikologis peserta didik. Dampak yang dirasakan oleh guru adalah peserta didik akan menganggap bahwa guru merupakan momok yang menakutkan bagi peserta didik. Sehingga terjadilah kesenjangan antara guru dan peserta didik. Hal yang sangat berpengaruh adalah proses penilaian kinerja guru yang tidak dapat terpenuhi secara keseluruhan. 


\section{Pengembangan Potensi Peserta Didik}

Guru harus mampu menganalisa potensi pembelajaran setiap peserta didik dan mengidentifikasi pengembangan potensi peserta didik melalui program pembelajaran yang mendukung siswa mengaktualisasikan potensi akademik, kepribadian dan kreativitasnya.

Adapun indikator kompetensi atau kinerja pengembangan potensi peserta didik adalah sebagai berikut :

a. Guru menganalisa hasil belajar berdasarkan segala bentuk penilaian terhadap setiap peserta didik untuk mengetahui tingkat kemajuan masing-masing

b. Guru merancang dan melaksanakan aktivitas pembelajaran yang mendorong peserta didik sesuai dengan kecakapan dan pola belajar masing-masing

c. Guru merancang dan melaksanakan aktivitas pembelajaran untuk memunculkan daya kreativitas dan kemampuan berpikir kritis peserta didik

d. Guru secara aktif membantu peserta didik dalam proses pembelajaran dan memberikan perhatian kepada setiap individu

e. Guru dapat mengidentifikasi denga benar tentang bakat, minat, potensi dan kesulitan belajar masing-masing peserta didik

f. Guru memberikan kesempatan belajar kepada peserta didik sesuai dengan cara belajarnya masing-masing.

g. Guru memusatkan perhatian pada interaksi dengan peserta didik dan mendorongnya untuk memahami dan menggunakan informasi yang disampaikan

Dari hasil penilaian dan pengamatan tersebut diperoleh gambaran bahwa pada indikator ke 1, 3, 5 dan 6 memperoleh skor 2 (terpenuhi seluruhnya) dan pada indikator 2, 4 dam 7 memperoleh skor 1 (terpenuhi sebagian). Sehingga total skor untuk kompetensi 5 adalah 11. Skor maskimum untuk kompetensi 5 adalah 14. Sehingga persentase yang diperoleh oleh guru Pendidikan Agama Islam adalah $75,7 \%$ dengan nilai 4 (kinerja yang baik).

Sesuai dengan hasil pengamatan pembelajaran, ada beberapa indikator yang paling menonjol yaitu setelah guru merancang pembelajaran, guru memberikan kesempatan belajar dan berpikir kepada peserta didik agar dapat mengembangkan potensi belajar yang dimiliki oleh peserta didik.

Dari hasil analisis penulis, diperoleh fakta bahwa guru sudah memiliki RPP dan silabus sebagai pedoman bagi guru dalam melaksanakan proses pembelajaran. Hal ini akan berdampak bagi peserta didik, karena akan menghambat kecakapan dan potensi yang dimiliki oleh setiap peserta didik, karena peserta didik tidak diberikan kebebasan berpikir secara kreatif dan berpartisipasi aktif dalam 
pembelajaran. Di sisi lain guru dianggap belum mampu berinteraksi dengan peserta didik yang mempunyai potensi yang beragam dan belum mampu untuk menciptakan proses belajar yang kreatif.

Untuk dapat mewujudkan suasana pembelajaran yang dapat dinikmati oleh seluruh peserta didik guru harus memberikan kesempatan kepada peserta didik untuk bermain dan berkreativitas. Sesuai dengan hasil penilaian guru Pendidikan Agama Islam di SMA Negeri 1 Tapa bahwa guru belum mampu secara aktif membantu peserta didik dalam proses pembelajaran dan belum mampu memberikan perhatian kepada setiap peserta didik. Selain itu guru belum mampu berinteraksi dengan peserta didik dalam memahami informasi materi yang disampaikan. Hal ini akan berdampak terhadap perkembangan kreativitas setiap peserta didik dalam kebebasan berpikir kreatif dan berpartisipasi secara aktif. Dampak lain yang ditimbulkan adalah hal tersebut dapat pula menghambat proses perkembangan psikologis setiap peserta didik. Peserta didik akan merasa dikucilkan, terlebih bagi peserta didik yang memiliki tingkat kemampuan dan pemahaman rendah. Dampak bagi kinerja guru Pendidikan Agama Islam adalah pada hakikatnya guru belum mampu menguasai karakteristik setiap peserta didik sehingga berpengaruh terhadap proses penilaian kompetensi guru itu sendiri.

\section{Komunikasi dengan Peserta Didik}

Berkomunikasi dengan peserta didik sangatlah penting bagi guru dalam proses pembelajaran. Dengan berkomunikasi guru dapat menyampaikan pesan berupa informasi, gagasan, arahan dan harapan dan suatu penjelasan materi pembelajaran kepada peserta didik. Melalui komunikasi, guru juga dapat memotivasi dan menggerakkan peserta didik untuk giat belajar, serta menjalin hubungan yang erat denga para peserta didik yang diperlukan bagi kelancaran proses pembelajaran. Oleh karena itu seorang guru harus mampu berkomunikasi secara baik dan efektif dengan peserta didik. Indikator kompetensi atau kinerja pada komunikasi dengan peserta didik adalah sebagai berikut:

a. Guru menggunakan pertanyaan untuk mengetahui pemahaman dan menjaga partisipasi peserta didik termasuk memberikan pertanyaan terbuka yang menuntut peserta didik untuk menjawab dengan ide dan pengetahuan mereka

b. Guru memberikan perhatian dan mendengarkan semua pertanyaan dan tanggapan peserta didik tanpa menginterupsi kecuali jika diperlukan untuk mengklarifikasi pertanyaan tersebut

c. Guru menanggapi pertanyaan peserta didik secara tepat, benar dan mutakhir sesuai tujuan pembelajaran dan isi kurikulum 
d. Guru menyajikan kegiatan pembelajaran yang dapat menumbuhkan kerja sama yang baik antar peserta didik

e. Guru mendengarkan dan memberikan perhatian terhadap semua jawaban peserta didik baik yang benar maupun yang dianggap salah untuk mengukur tingkat pemahaman peserta didik

f. Guru memberikan perhatian terhadap pertanyaan peserta didik dan meresponnya secara lengkap dan relevan untuk menghilangkan kebingungan pada peserta didik.

Dari hasil penilaian diperoleh nilai untuk kompetensi 6 adalah 4. Dari 6 indikator yang dinilai, 5 indikator rata-rata memperoleh skor 2 (terpenuhi seluruhnya) dan indikator ke 6 memperoleh nilai 1 (terpenuhi sebagian) sehingga total skor adalah 11. Adapun skor maksimumnya adalah 12 , sehingga dari hasil pembagian persentase diperoleh nilai untuk kompetensi 6 adalah 4 (kinerja yang baik).

Adapun analisa penulis untuk pengamatan lapangan bahwa pada aspek kompetensi 6 ini adalah adanya ketidaksesuaian antara indikator 2 dan indikator 6. Pada indikator 2 guru Pendidikan Agama Islam memperoleh skor 2 yakni "guru memberikan perhatian dan mendengarkan semua pertanyaan dan tanggapan peserta didik, tanpa menginterupsi, kecuali jika diperlukan untuk membantu atau mengklarifikasi pertanyaan/tanggapan tersebut". Sedangkan pada indikator 6 guru Pendidikan Agama Islam memperoleh skor 1 yakni "guru memberikan perhatian terhadap pertanyaan peserta didik dan meresponnya secara lengkap dan relevan untuk menghilangkan kebingungan pada peserta didik". Dari penjelasan indikator ke 2 dan indikator ke 6 tersebut dapat disimpulkan bahwa terjadi tumpang tindih dalam pemberian nilai bagi guru. Karena pada dasarnya kedua indikator tersebut harus memperoleh nilai yang sama.

Dari hasil pengamatan penilaian kompetensi komunikasi dengan peserta didik dapat disimpulkan bahwa guru belum mampu memberikan perhatian terhadap pertanyaan peserta didik dan guru belum mampu meresponnya secara lengkap dan relevan. Adapun kendala yang dihadapi oleh guru adalah guru belum mampu mengembangkan materi dengan cara penyampaian yang belum tentu jelas bagi guru tersebut. Sehingga akan berdampak bagi peserta didik selaku penerima informasi yang disampaikan. Hal ini tentunya akan menghambat proses pembelajaran dan menghambat proses komunikasi dua arah dalam pembelajaran. ${ }^{14}$ Adapun dampak yang

\footnotetext{
${ }^{14}$ Zakaria, D., \& Ibrahim, S. (2019). Efektivitas Bimbingan Belajar Mandiri dan Implikasinya terhadap Hasil Belajar Pendidikan Agama Islam Peserta Didik di SMK Negeri 3 Gorontalo. Jurnal Ilmiah AL-Jauhari: Jurnal Studi Islam Dan Interdisipliner, 3(2), 1-18.
} 
ditimbulkan bagi guru adalah guru sulit memahami materi yang disampaikan sehingga sulit merespon setiap pertanyaan peserta didik. Guru dianggap belum mampu mendesain pembelajaran yang dapat menciptakan komunikasi dua arah yang efektif. Karena komunikasi dikatakan efektif apabila terdapat aliran informasi dua arah antara guru dan peserta didik serta informasi tersebut sama-sama direspon sesuai dengan harapan. Tanpa komunikasi yang efektif tidak akan terjadi pembelajaran yang efektif.

\section{Penilaian dan Evaluasi}

Evaluasi atau penilaian hasil belajar adalah segala macam prosedur yang digunakan untuk mendapatkan informasi mengenai untuk kerja (performance) peserta didik atau seberapa jauh peserta didik dapat mencapai tujuan-tujuan pembelajaran yang telah ditetapkan. $^{15}$

Dengan kompetensi ini diharapkan guru menyelenggarakan penilaian proses dan hasil belajar secara berkesinambungan. Guru melakukan evaluasi atas efektivitas proses dan hasil belajar dan menggunakan informasi hasil penilaian dan evaluasi untuk merancang program remedial dan pengayaan. Indikator kompetensi penilaian dan evaluasi yang harus dilaksanakan oleh guru adalah sebagai berikut:

a. Guru menyusun alat penilaian yang sesuai dengan tujuan pembelajaran untuk mencapai kompetensi tertentu seperti yang tertulis dalam RPP.

b. Guru melaksanakan penilaian dengan berbagai teknik dan jenis penilaian selain penilaian formal yang dilaksanakan sekolah dan mengumumkan hasil serta implikasinya kepada peserta didik, tentang tingkat pemahaman terhadap materi pembelajaran yang telah dan akan dipelajari

c. Guru menganalisis hasil penilaian untuk mengidentifikasi topik/kompetensi dasar yang sulit sehingga diketahui kekuatan dan kelemahan masing-masing peserta didik untuk keperluan remedial dan pengayaan.

d. Guru memanfaatkan masukan dari peserta didik dan merefleksikannya untuk meningkatkan pembelajaran selanjutnya dan dapat membuktikannya melalui catatan, jurnal pembelajaran, rancangan pembelajaran, materi tambahan dan sebagainya

e. Guru memanfaatkan hasil penilaian sebagai bahan penyusunan rancangan pembelajaran yang akan dilakukan selanjutnya

Dari hasil penilaian kinerja guru untuk kompetensi pedagogik pada aspek 6 bahwa guru Pendidikan Agama Islam memperoleh nilai

\footnotetext{
${ }^{15}$ Eveline Siregar dan Hartini Nara, Teori Belajar dan Pembelajaran, (Bogor: Ghalia Indonesia, 2010), h. 144
} 
4. Dari 5 indikator yang dinilai, rata-rata guru Pendidikan Agama Islam memperoleh skor 2 (terpenuhi seluruhnya), sehingga mencapai skor masksimum 10. Dalam perhitungan persentase nilai yang dicapai adalah 100, sehingga nilai untuk kompetensi 7 memperoleh nilai 4 .

Dari hasil observasi penilaian kompetensi pedagogik dan hasil wawancara secara keseluruhan untuk aspek penilaian dan evaluasi guru Pendidikan Agama Islam seluruh indikatornya telah terpenuhi seluruhnya. Hal ini menunjukkan kinerja yang baik bagi guru Pendidikan Agama Islam. Namun di sisi lain peneliti menemukan masalah penilaian pada aspek penilaian dan evaluasi. Pada aspek 7 diperoleh hasil analisis bahwa pada indikator ke 3 disebutkan guru dapat mengidentifikasi kompetensi dasar yang sulit, sehingga dapat diketahui kekuatan dan kelemahan masing-masing peserta didik. Pada indikator tersebut guru Pendidikan Agama Islam memperoleh skor 2 (terpenuhi seluruhnya). Pada kompetensi 1 (mengenal karakteristik peserta didik) indikator 5 disebutkan bahwa guru membantu mengembangkan potensi dan mengatasi kekurangan peserta didik. Pada indikator tersebut, guru Pendidikan Agama Islam memperoleh skor 1 (terpenuhi sebagian). Telah terjadi ketimpangan penilaian antara kompetensi 1 indikator 5 dan kompetensi 7 indikator 3 . Hal yang perlu mendapat penegasan di sini adalah adanya keterkaitan yang erat seluruh aspek dan seluruh indikator yang ada pada kompetensi pedagogik.

Tidak sesuainya proses penilaian ini tentunya memberikan dampak terhadap hasil akhir penilaian kompetensi pedagogik guru Pendidikan Agama Islam. Guru yang melakukan penilaian terhadap guru Pendidikan Agama Islam dituntut untuk lebih objektiv dalam mengamati dan memberikan penilaian. Karena dampak dari tidak obejktivitasnya dalam pemberian nilai akan berpengaruh terhadap penilaian kinerja guru secara keseluruhan.

\section{Pengaruh Kinerja Guru dan Dampak Pelaksanaan Standar Penilaian Kompetensi Pedagogik}

1. Motivasi Kinerja Guru

Dorongan untuk melaksanakan pekerjaan dengan baik bagi guru Pendidikan Agama Islam sebaiknya muncul dari dalam diri sendiri, tetapi upaya motivasi dari luar juga dapat juga memberikan semangat kerja guru, misalnya dorongan yang diberikan dari kepala sekolah kepada guru.

Adapun semangat lain yang diberikan oleh pihak sekolah sendiri adalah dengan memberikan reward bagi guru berprestasi. Hal ini dimaksudkan agar dapat menjadi penyemangat bagi guru lainnya dan motivasi bagi guru untuk lebih meningkatkan kinerjanya. 


\section{Etos Kinerja Guru}

Guru Pendidikan Agama Islam memiliki etos kerja yang lebih besar untuk berhasil dalam melaksanakan proses belajar mengajar dibandingkan dengan guru yang tidak ditunjang oleh etos kinerja. Dalam melaksanakan tugasnya, guru Pendidikan Agama Islam harus memiliki etos yang berbeda-beda. Etos kerja perlu dikembangkan oleh guru, karena:

a. Pergeseran waktu yang mengakibatkan segala sesuatu dalam kehidupan manusia berubah dan berkembang.

b. Kondisi yang terbuka untuk menerima dan menyalurkan kreativitas.

c. Perubahan lingkungan terutama bidang teknologi.

3. Lingkungan Kinerja Guru

Lingkungan kerja yang dapat mendukung guru Pendidikan Agama Islam melaksanakan tugas secara efektif dan efisien, meliputi:

a. Lingkungan sosial-psikologis, yaitu lingkungan serasi dan harmonis antar guru, guru dengan kepala sekolah, dan guru, kepala sekolah, dengan staf TU dapat menunjang berhasilnya kinerja guru.

b. Lingkungan fisik, ruang kinerja guru hendaknya memenuhi syarat-syarat sebagai berikut: (1) Ruangan harus bersih, (2) Ada ruangan khusus untuk kerja, (3) Peralatan dan perabotan tertata baik, (4) Mempunyai penerangan yang baik, (5) Tersedia meja kerja yang cukup, (6) Sirkulasi udara yang baik, dan (7) Jauh dari kebisingan.

4. Tugas dan Tanggung jawab Guru meliputi :

Tugas dan tanggung jawab guru Pendidikan Agama Islam

a. Tanggung jawab moral, guru harus memiliki kemampuan menghayati perilaku dan etika yang sesuai dengan moral Pancasila.

b. Tanggung jawab dan proses pembelajaran di sekolah, yaitu setiap guru harus menguasai cara pembelajaran yang efektif, mampu membuat persiapan mengajar dan memahami kurikulum dengan baik.

c. Tanggung jawab guru di bidang kemasyarakatan, yaitu turut mensukseskan pembangunan masyarakat, untuk itu guru harus mampu membimbing, mengabdi, dan melayani masyarakat.

d. Tanggung jawab guru di bidang keilmuan, yaitu guru turut serta memajukan ilmu dengan melaksanakan penelitian dan pengembangan.

e. Optimalisasi kelompok kerja guru 
Kinerja guru Pendidikan Agama Islam yang efektif dan efisien akan menghasilkan sumber daya manusia yang tangguh, yaitu lulusan yang berdaya guna dan berhasil guna sesuai dengan tujuan yang telah ditetapkan. Oleh karena itu, Kinerja guru dalam proses pembelajaran perlu ditingkatkan sebagai upaya mengembangkan kegiatan yang ada menjadi lebih baik, yang berdasarkan kemampuan bukan kepada asalusul keturunan atau warisan, juga menjunjung tinggi kualitas, inisiatif dan kreativitas, kerja keras dan produktivitas.

Kompetensi pedagogik merupakan salah satu kompetensi yang menjadi penilaian bagi kinerja guru. Seluruh indikator yang terdapat pada kompetensi pedagogoik harus benar-benar diimplementasikan dalam proses pembelajaran agar tujuan pembelajaran yang sebenarnya dapat tercapai. Dari hari penelitian kompetensi pedagogik terhadap penilaian kinerja guru Pendidikan Agama Islam di SMA Negeri 1 Tapa, telah memberikan pengaruh yang signifikan terhadap penilaian kinerja guru Pendidikan Agama Islam dan proses pembelajaran bagi peserta didik.

Pada pembahasan ini, peneliti akan menyoroti dua aspek dari dampak pelaksanaan standar penilaian kompetensi pedagogik terhadap kinerja guru Pendidikan Agama Islam di SMA Negeri 1 Tapa, yakni dampak positif dan dampak negatif.

Standar penilaian kompetensi pedagogik guru berfungsi untuk mengetahui kemampuan guru dalam mengelola pembelajaran bagi peserta didik secara berkesinambungan dengan mengacu pada indikator kompetensi pedagogik. Selain itu pula, dimensi kinerja guru dapat menjadi acuan bagi guru Pendidikan Agama Islam sebagai upaya dalam meningkatkan kinerja guru. Hasil dari keterpaduan antara kompetensi pedagogik dan dimensi kerja tersebut diharapkan untuk peserta didik dapat melahirkan peserta didik yang berkualitas, sekaligus memiliki pengetahuan dan keterampilan serta akhlak, sehingga diharapkan mampu berkompetisi sesuai dengan tuntutan zaman. adalah;

Adapun dampak positif penilaian kompetensi pedagogik guru

a. Meningkatkan efisiensi dan efektivitas kinerja guru Pendidikan Agama Islam dan sekolah;

b. Menyediakan landasan untuk program pengembangan keprofesian berkelanjutan bagi guru Pendidikan Agama Islam;

c. Menyediakan dasar dalam sistem peningkatan promosi dan karir guru serta bentuk penghargaan lainnya;

d. Sebagai bagian dari proses pengembangan karir dan promosi guru untuk kenaikan pangkat dan jabatan fungsionalnya. 
Bagi guru penilaian kompetensi pedagogik dapat dijadikan sebagai pedoman dalam rangka meningkatkan proses pembelajaran sekaligus sebagai bahan evaluasi bagi guru dalam rangka peningkatan karir guru Pendidikan Agama Islam itu sendiri. Oleh sebab itu, hasil dari evaluasi penilaian kompetensi pedagogik guru PAI bukan sekedar dijadikan sebagai beban bagi guru itu sendiri ataupun sekedar pemenuhan kebutuhan administrasi bagi guru Pendidikan Agama Islam.

\section{Kesimpulan}

Pelaksanaan standar penilaian kompetensi pedagogik guru mata pelajaran Pendidikan Agama Islam di SMA Negeri 1 Tapa, pada dasarnya telah diimplementasikan berdasarkan indikator-indikator yang telah ditetapkan. Namun peneliti menemukan beberapa masalah di lapangan, yakni (a) belum maksimalnya implementasi seluruh indikator yang ada pada kompetensi pedagogik, (b) adanya ketidaksesuaian antara proses pembelajaran dan indikator yang dicapai oleh guru PAI, (c) adanya ketidaksesusian antara hasil pengamatan belajar dan skor yang diperoleh oleh guru PAI, (d) terjadi tumpang tindih antara nilai indikator yang satu dengan nilai indikator lainnya, (e) pembelajaran guru PAI lebih berorentasi pada hasil belajar, bukan pada proses pembelajaran, (f) guru PAI lebih berorientasi pada RPP dan silabus yang ada tanpa adanya kreativitas guru dalam menciptakan proses pembelajaran yang lebih efektif, (g) tidak adanya upaya dari guru untuk melakukan refleksi terhadap hasil evaluasi dan penilaian dari peserta didik, (h) penilaian terhadap kinerja guru PAI belum sepenuhnya dilakukan secara objektif.

\section{Daftar Pustaka}

Antonius, Buku Pedoman Guru, Bandung: Yrama Widya, 2015.

Arikunto, Suharsimi. Prosedur Penelitian Suatu Pendekatan Praktek, Jakarta: Rineka Cipta, 1997.

Balqis, Putri dkk., "Kompetensi Pedagogik Guru dalam Meningkatkan Motivasi Belajar Siswa”, dalam Jurnal Administrasi Pendidikan Pascasarjana Universitas Syiah Kuala, Volume 2 No. 1, Agustus tahun 2014.

Burhanuddin, Afid Pengumpulan Data dan Instrumen Penelitian, https://afidburhanuddin.wordpress.com/2013/05/21 pengumpul an-data-dan-instrumen-penelitian-3/, diakses tanggal 08 Maret 2017. 
Departemen Pendidikan Nasional, Assesment Berbasis Kelas, Jakarta: Pusat Penelitian Pendidikan Balitbang, 2008.

Diknas Dirjen Dikdasmen, Standar Kompetensi Guru Menengah Atas, Jakarta: 2004.

Dimyati dan Mudjiono, Belajar dan Pembelajaran, Jakarta: PT. Rineka Cipta, 2006.

Dwi Eny Lailatul Badriyah, Pengaruh Kompetensi Guru, Sertifikasi dan Motivasi Kerja Terhadap Kinerja Guru Rumpun PAI di MAN se Kabupaten Blitar. Tesis, Program Studi Pendidikan Agama Islam, IAIN Tulung Agung, Tahun 2015

Fatimah, Ana Kompetensi Pedagogik Guru Pendidikan Agama Islam dan Budi Pekerti Dalam Pembelajaran Saintifik Berbasis Discovery Learning Di SMP Negeri 1 Prambanan Sleman. Skripsi, Ilmu Tarbiyah dan Keguruan UIN Sunan Kalijaga Yogyakarta, Tahun 2015

H.E. Mulyasa, Uji Kompetensi dan Penilaian Kinerja Guru, Bandung: PT. Remaja Rosdakarya, 2013

Ilyas, Yaslis, Kinerja: Teori, Penilaian, dan Penelitian. Depok: FKMUI, 2002.

Irwanto, Nur dan Yusuf Suryana, Kompetensi Pedagogik; Untuk Peningkatan dan Penilaian Kinerja Guru dalam Rangka Implementasi Kurikulum Nasional, Surabaya: Genta Group Production, 2016

Kementerian Pendidikan Indonesia, Peraturan Menteri Pendidikan Nasional Nomor 35 Tahun 2010 Tentang Petunjuk Teknis Pelaksanaan Jabatan Fungsional Guru dan Angka Kreditnya, Jakarta: 2010

Majid Abdul dan Dian Andayani, Pendidikan Karakter Perspektif Islam, Bandung: PT. Remaja Rosdakarya, 2012

Mukhlisin, "Profesionalisme Kinerja Guru dalam Menyongsong Masa Depan”, dalam http://teknologipendidikanuia.blogspot.co.id/2011/03/hakikat-kinerja-guru.html, diakses tanggal 21 Januari 2016.

Mustafa, Jejen, Peningkatan Kompetensi Guru; Melalui Pelatihan dan Sumber Belajar Teori dan Praktik, Jakarta: Kencana Prenada Media Group, 2011.

Narsoyo, Tedjo Reksoatmodjo. Pengembangan Kurikulum Pendidikan Teknologi dan Kejuruan, Bandung; PT. Refika Aditama, 2010.

Nata, Abuddin, Kapita Selekta Pendidikan Islam; Isu-isu Kontemporer tentang Pendidikan Islam, Jakarta: PT. RajaGrafindo Persada, 2013

Nata, Abuddin Ilmu Pendidikan Islam, Jakarta: Kencana Prenada Media Group, 2010. 
Permendiknas RI No. 16 Tahun 2009 Tentang Jabatan Fungsional

Guru dan Angka Kreditnya, dalam http://kitaabati.blogspot.com/2012/12/ permendiknas-ri-no-19tahun- 2005.html, diakses tanggal 03 Maret 2017

Priatna, Nanang \& Tito Sukamto, Pengembangan Profesi Guru, Bandung: PT Remaja Rosdakarya, 2013.

Ratnawati, Yuni. Kompetensi Pedagogik Guru Sekolah Dasar se Kecamatan Kretek Kabupaten Bantul. Skripsi, Ilmu Pendidikan Universitas Negeri Yogyakarta, Tahun 2012

Sanjaya, Wina. Strategi Pembelajaran Berorientasi Standar Proses Pendidikan, Jakarta: Kencana Prenada Media Group, 2009.

Sudrajat, Akhmad. "Aspek dan Indikator Kompetensi Pedagogik Guru”.http://akhmadsudrajad.wordpress.com/2012/01/29/aspe k-dan indikatorkompetensi-pedagogik-guru/. diakses tanggal 28 November 2015.

Sulistyorini, "Hubungan Antara Keterampilan Manajerial Kepala Sekolah dan Iklim Organisasi dengan Kinerja Guru", dalam Jurnal Ilmu Pendidikan, Volume 28 nomor 1 tahun 2001.

Supardi, Kinerja Guru, Jakarta: PT. RajaGrafindo Persada, 2014.

Undang-Undang RI No. 14 Th 2005, Tentang Guru dan dosen, Jakarta: Asa Mandiri, 2007.

Usman Uzer, Menjadi Guru Profesional, Cet ke I, Remaja Rosdakarya: Bandung, 2003.

Zakaria, D., \& Ibrahim, S. (2019). Efektivitas Bimbingan Belajar Mandiri dan Implikasinya terhadap Hasil Belajar Pendidikan Agama Islam Peserta Didik di SMK Negeri 3 Gorontalo. Jurnal Ilmiah AL-Jauhari: Jurnal Studi Islam Dan Interdisipliner 